Adıyaman Üniversitesi Sağlık Bilimleri Dergisi, 2020;6(1):1-12

doi:10.30569.adiyamansaglik.608931

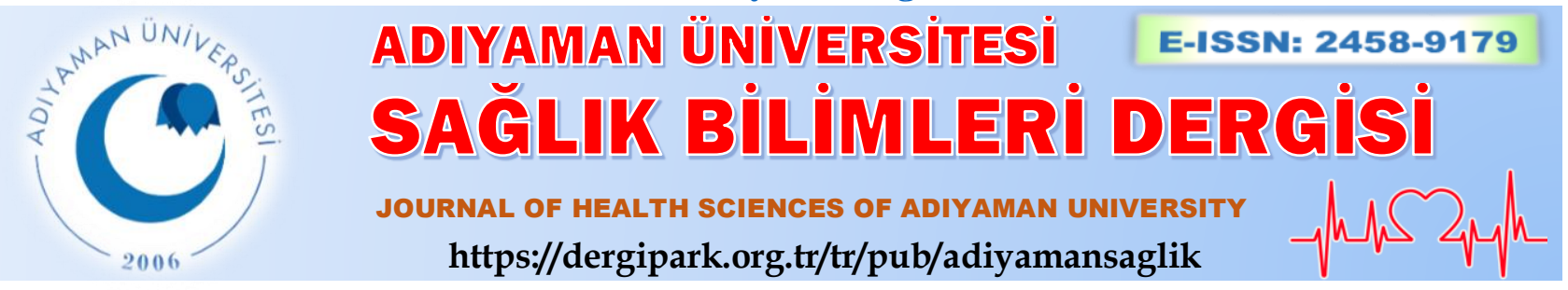

Özgün Araştırma/Research Article

\title{
Hemodiyaliz tedavisi alan kronik böbrek yetmezliği hastalarının yaşam deneyimlerinin incelenmesi
}

\section{Chronic renal failure patients receiving hemodialysis treatment examination of life experiences}

\author{
Figen ALBAYRAK OKÇİN ${ }^{1 @(D), ~ O ̈ z n u r ~ U S T A ~ Y E S ̧ I L B A L K A N ~}{ }^{1}$ \\ ${ }^{1}$ Ege Üniversitesi, Hemşirelik Fakültesi, Hemşirelik Bölümü, İç Hastalıkları Hemşireliği Anabilim Dalı, 35100, İzmir- \\ Türkiye
}

Atıf gösterme/Cite this article as: Okçin Albayrak F, Yeşilbalkan Usta Ö. Hemodiyaliz tedavisi alan kronik böbrek yetmezliği hastalarının yaşam deneyimlerinin incelenmesi. ADYÜ Sağllk Bilimleri Derg. 2020;6(1):1-12. doi:10.30569.adiyamansaglik.608931

$\ddot{O} \mathbf{z}$

Amaç: Hemodiyaliz tedavisi alan KBY hastalarının bireysel yaşam deneyimlerinin incelenmesidir.

Gereç ve Yöntem: Niteliksel-fenomenolojik tipte tasarlanan bu araştırma Ege Üniversitesi Hastanesi Hemodiyaliz Ünitesinde Şubat-Mart 2017 tarihleri arasında toplam 15 hasta ile yürütülmüş̧ür. Verilerin analizinde içerik analizi yöntemi kullanılmıştır. Veri toplama araçları olarak hasta soru formu ve yarı yapılandırılmış görüşme formu kullanılmıştır. Görüşmelerde ses kaydı alınmıştır.

Bulgular: Hastaların yaş ortalamaları $54,2 \pm 16,80$ olarak hesaplanmıştır. İçerik analizi sonucunda "bireysel boyut", "aile ve sosyal çevre boyutu", "kurumsal boyut" olmak üzere toplam 3 tema, bunların altında yer alan 9 alt tema belirlenmiştir.

Sonuç: Araştırma sonuçlarına göre katılımcıların fiziksel ve psikolojik olarak desteklenmeye ihtiyaç duydukları belirlenmiştir. Katılımcıların eş, aile ve sosyal destek gereksinimlerini yönetebilmeleri konusunda gereken danışmanlık hizmetlerinin sağlanmasının önemli olduğu saptanmıştır. Tedavi sürecinde hizmet aldıkları kurumdaki ekip yaklaşımı ve ekibin uyumunun önemli olduğu ifade edilmiştir.

Anahtar Kelimeler: Fenomenolojik araştırma; Hemodiyaliz; Kronik böbrek yetmezliği; Hemşirelik.

\begin{abstract}
Aim: The aim of this study was to evaluate how patients interpreted the events in their lives from hemodialysis treatment from their own perspectives.

Materials and Methods: The research was designed as qualitative-phenomenological type. The study was carried out in the Hemodialysis unit of Ege University Hospital between February-March 2017. A total of 15 patients participated. Content analysis method was used for data analysis. Data collection tools, patients questionnaires, semi-structuredquestions were used. Voice recordings were taken during the interviews.

Results: The mean age of the patients was $54.2 \pm 16.80$. As a result of the thematic analyzes, three main themes emerged: "Individual dimention", "Family and social environment dimention", and "Institutional dimention"corporate size. Nine sub-themes were identified.

Conclusion: According to the results of the research, it was determined that the participants needed physical and psychological support. It was found that is important to provide the necessary counseling services for the participants to manage their spouse, family and social suppurt needs. It is stated that the team approach and the harmony of the team in the institution they receive service during the treatment process are important.

Keywords: Phenomenological research; Hemodialysis; Chronic renal failure; Nursing.
\end{abstract}

Yazışma Adresi/Address for Correspondence: Dr. Figen ALBAYRAK OKÇİN, Ege Üniversitesi, Hemşirelik Fakültesi, Hemşirelik Bölümü, İç Hastalıkları Hemşireliği Anabilim Dalı, 35100, İzmir-Türkiye, E-mail: figen.okcin @ gmail.com

Geliş Tarihi/Received:21.08.2019 Kabul Tarihi/Accepted:27.03.2020

Yayım Tarihi/Published online:23.04.2020 


\section{Giriş}

Kronik Böbrek Yetmezliği (KBY) tüm Dünya'da yaygın olarak görülen, böbrek yap1 ve fonksiyonlarında meydana gelen bozukluklarla karakterize, yaşamı tehdit eden, iş gücü kaybına, çeşitli komplikasyonlara neden olabilen, kötü prognoza sahip, mortalite riski olan kronik bir hastalıktır. ${ }^{1,2}$ Renal Replasman Tedavi (RRT) yöntemlerinden biri olan diyaliz uygulaması Son Dönem Böbrek Yetmezliği (SDBY) gelişen hastalarda kullanılan bir tedavi seçeneğidir. Ülkeler arasındaki farklılıklara rağmen, tüm dünyada diyaliz yöntemleri arasında ortalama $\% 90$ oranında hemodiyaliz (HD) yöntemi uygulanmaktadır. Ülkemizde Türk Nefroloji Derneği (TND) verilerine göre 2018 yılı sonu itibariyle ülkemizde $\% 74,8$ hemodiyaliz uygulaması yapılmaktadır. ${ }^{3}$

Ülkemizde diyaliz uygulaması, son dönem böbrek hastalarına donör bulmaktaki güçlükler nedeniyle zorunlu bir tercih olmaktadır. $^{4}$ Kronik hastalıklarla yaşayan hastaların yaşam kalitelerinde bozulma olduğu ve yüksek düzeyde depresyonla ilişkili olarak mental sağlık sorunları yaşadıkları da belirtilmektedir. ${ }^{5} \mathrm{HD}$, hasta birey ve ailesi için psikolojik, sosyal ve ekonomik sorunları beraberinde getiren bir süreçtir. ${ }^{6}$ HD hastalarında, kronik bir hastalığın beraberinde getirdiği tıbbi ve psikososyal sorunlara ek olarak, hemodiyaliz uygulaması ile ilişkili öfke, kayg1, mutsuzluk ve korku gibi olumsuz duyguların yaşanması da söz konusudur. ${ }^{7}$ Diğer kronik bakım gereksinimi olan hastalıklarda olduğu gibi, kronik böbrek yetmezliğinde hastanın eğitimi, sağlığın korunması ve geliştirilmesine yönelik hizmetlerin sunulmasında, uzmanlık alan bilgisine sahip sağlı profesyonelleri son derece önemlidir. Clarkson ve Robinson yapmış oldukları çalışmada, hemşirelerin erken müdahalelerinin, hasta ve aileleri için yaşam kalitesinin arttırılmasında kazanç sağladığı ve bakımın tıbbi maliyetlerini düşürdüğünü ortaya koymuşlardır. ${ }^{8}$

Hasta eğitimi, sağ lığın korunması, hastanın uyumunun desteklenmesi, iyi bir taburculuk planlaması, evde bakım konusunda yaşananların ve beklentilerin doğru tanımlanmasıyla ilişkilidir. Günlük bakım uygulamaları içinde bazen hastalarla istenen kalitede zaman paylaşımı sağlanamamasına karşın, çalıştıkları hasta grubunun özelliğinden dolayı, hemodiyaliz hastalarıyla daha çok bir arada olan nefroloji hemşirelerinin hastaları doğru tanımlaması ve ihtiyaçlarını anlayabilmeleri hayati önem taşımaktadır. $^{9}$

Araştırmanın amacı; hemodiyaliz tedavisi alan KBY hastalarının bireysel yaşam deneyimlerinin incelenmesidir. Elde edilecek verilerin hastaların yaşam kalitelerinin yükseltilmesine doğrudan veya dolaylı olarak bakım, tedavi ve eğitim içeriklerinin planlanmasında yarar sağlayacağ 1 düşünülmektedir.

\section{Gereç ve Yöntem}

$\mathrm{Bu}$ araştırma, niteliksel-fenomenolojik bir çalışma olarak yapılmıştır. Araştırma; Ege Üniversitesi Hastanesi, Hemodiyaliz Ünitesinde, Şubat-Mart 2017 tarihinde yürütülmüştür. Araştırmanın evrenini, KBY tanisı alan ve kuruma HD tedavisi almak üzere başvuran hastalar oluşturmuştur. Araştırmaya dâhil edilme kriterleri, HD tedavisi alan ve çalışmaya katılmayı kabul eden hastalar olarak belirlenmiştir. Niteliksel araştırma kapsamına alınacak kişi sayısına yönelik kesin bir kural belirtilmemekle beraber örneklem belirlemede pek çok yöntemden çalışma tasarımına en uygun olan kullanılmalıdır., ${ }^{9,10}$ Çalışmamızda amaçlı rastgele örnekleme yöntemi kullanılmıştır. $\mathrm{Bu}$ yöntemde, araştırmacı öncelikle rasgele yöntemleri kullanarak evrenden bir örneklem grubu belirlemekte ve daha sonra bu grup içinden araştırmaya en çok katkı yapacağını düşündügü küçük bir alt grubu seçmektedir. ${ }^{11,12}$ Örneklemi, HD tedavisi alan 15 hasta oluşturmuştur. Veri toplama araçları olarak; araştırmacılar tarafindan hazırlanan, Hasta Soru Formu ve yarı yapılandırılmış görüşme formu kullanılmıştır. Nitel araştırmalarda üç tür yöntem kullanılmaktadır. Bunlar, görüşme, gözlem ve yazılı doküman incelemesidir. Görüşme yönteminde, açık uçlu, yapılandırılmış veya yarı yapılandırılmış sorular kullanılabilir. ${ }^{9,13}$

Hasta Soru Formunda; hastaya ilişkin yaş, cinsiyet, medeni durum, sosyal güvence, 
eğitim durumu, gelir düzeyi, kiminle yaşadığı, kronik hastalık öyküsü, KBY hastası olma süresi, HD girme süresi gibi soruların yer aldığ1 toplam 10 soru yer almaktadır. Araştırmanın tasarımı aşamasında, nitel araştırma yöntemleri dersleri veren, bir üniversite hastanesinde görevli, tıp uzmanı bir akademisyenden danışmanlık alınmıştır. Soruların hazırlanması aşamasında, bir üniversitede görevli, psikiyatri hemşireliği anabilim dalında akademisyen bir öğretim üyesi tarafindan uzman görüşü alınmıştır. Araştırmada yer alan yarı yapılandırılmış görüşme formu soruları:

1. Hemodiyalize giren bir hasta olmak sizin için ne anlama geliyor?

2. Hemodiyalize giren bir hasta olmak size ne hissettiriyor?

3. Hemodiyalize giren bir hasta olmak hayatınızda en fazla neleri etkiliyor?

Katılımcılara görüşme öncesinde araştırmanın amac1, veri toplama yöntemi açıklanmış, sözlü ve yazılı onamları alınan hastalarla görüşmeler, HD işlemi sırasında yapılmış ve aynı zamanda ses kayıtları alınmıştır. Görüşmelerde HD işlemi sırasında mümkün olan en sessiz ortam özellikleri sağlanmaya çalışılmış ve hastanın kendini rahat hissedebildiği sürece görüşme sürdürülmüştür. Görüşme süreleri $10 \mathrm{dk}-40$ $\mathrm{dk}$ arasında değişiklik göstermiştir. Hastalar ile işlem sırasında görüşme, hastaların işlem sonrasında klinikte uzun süre kalmak istemediklerini ifade etmelerinden dolay1 gerçekleştirilmiştir. Görüşmeler ses kayıt cihazına kaydedildikten sonra her görüşme yazıya dökülmüştür.

Verilerin analizinde Graneheim ve Lundman içerik analizi yöntemi kullanılmış ve kodlama elle yapılmıştır. ${ }^{14}$ Yazılı dokümanlar araştırmacılar tarafindan tekrar tekrar okunduktan sonra, tekrarlayan ifadelerden oluşan kodlar belirlenmiş, tüm metinlerde ortak kodların birleştiği noktalarda alt temalar ortaya konulmuştur. Alt temaların altında toplandığ 1 çatılar tema olarak belirlenmiştir.

Çalışmamızda, geçerliği sağlamaya yönelik adımlardan, uzun süreli etkileşimin sürdürülmesi ve çalışma sonuçlarının aktarılabilir olmasını sağlamak için açık ve net ifadelerin yer aldığ 1 bir anlatım şekli kullanılmıştır. Güvenirliği sağlamaya yönelik; kapsamlı literatür araştırması, araştırma yönteminin, ortamın ve koşulların ayrıntılı açıklanması sağlanmıştır.

\section{Bulgular}

$\mathrm{Bu}$ araştırmada, hemodiyaliz tedavisi alan hastaların yaşam deneyimlerini içeren üç tema; "bireysel boyut, aile ve sosyal çevre boyutu ve kurumsal boyut" belirlenmiştir. Belirlenen alt temalar: kisitlilıklar (su, tuz ve diyet değişiklikleri), yorgunluk ve diğer komplikasyonlar (kan basıncı değişiklikleri, baş ağrısı, baş dönmesi, halsizlik), psikolojik zorluklar ve baş etme deneyimleri/destek alma gereksinimi, eş ve aile ilişkilerinde değişiklikler, sınırlı sosyal çevre, ekonomik boyut (iş kaybi/değişiklik), kurum deneyimlerine ilişkin zorluklar ve ekiple iletişimdir.

\section{Katılımcıların Tanıtıcı Özelliklerine İlişkin Bulgular}

Yaş ortalamaları $54,2 \pm 16,80$ olan katılımciların 5'i kadın, 10'u erkektir. Katılımcılardan 10 kişi evli, 5 kişi bekârdır. Katılımcıların HD işlemine girdikleri ortalama süre 7,03 (yıl) olarak hesaplanmıştır. Katılımcıların tamamına yakını haftada $3 \mathrm{kez}$ HD tedavisi almakta olup, diyaliz işlemi ortalama sadece 1 hasta için 4 saat, diğer hastalar için 5 saat sürmektedir. Hastaların 11'nin KBY dışında kronik bir hastalığ 1 bulunmaktadır (Tablo 1). Katılımciların yaşam deneyimleri incelenmiş, verilerin içerik analizlerinin ardından oluşturulan üç tema ve temalara ilişkin dokuz alt tema tanımlanmıştır (Tablo 2).

\section{Tema: Bireysel Boyut}

Çalışmamızda, HD tedavisi alan KBY hastaları yaşamlarında olan değişiklikleri farklı boyutlarda tanımlamışlardır. İlk tema; bireysel boyut altında yer alan kısitlilıklar; su, tuz ve diyet değişiklikleri, yorgunluk ve diğer komplikasyonlardır (kan basinc1 değişiklikleri, baş ağrısı, baş dönmesi, halsizlik hissi). Hastalar HD'e girdikleri gün herhangi bir iş yapmaktan kaçındıklarını ve o. günü sıklıkla dinlenerek geçirdikleri ifade 
edilmiştir. Hastalar aynı zamanda psikolojik olarak zorluklar yaşadıklarını belirtmişlerdir. $\mathrm{Bu}$ durumun en temel nedenleri olarak yaşadıkları bağımlılık duygusunu ve farklı şekillerde ifade ettikleri baş etme zorluklarını ifade etmişlerdir.

Tablo 1. Katılımcıların sosyo-demografik özelliklerine göre dağılımları.

\begin{tabular}{llcc}
\hline Demografik özellikler & & $\mathrm{n}$ & $\%$ \\
\hline Cinsiyet & Kadın & 10 & 66,7 \\
& Erkek & 5 & 33,3 \\
\hline \multirow{2}{*}{ Ĕ̆itim } & Ilk-orta öğretim & 4 & 26,7 \\
& Lise & 4 & 26,7 \\
\hline \multirow{2}{*}{ Medeni Durumu } & YO & 7 & 46,6 \\
\hline Yaş & Evli & 10 & 66,7 \\
Hemodiyaliz Tedavi Süresi (Yıl) & Bekar & 5 & 33,3 \\
Haftalık HD Girme Sıklığı (Haftalık) & Ortalama: 54,2 & SS: 16,80 & \\
Kronik Hastalığı Varlığı & Ortalama: 7,06 & SS: 6,21 & \\
& Ortalama: 3,20 & SS: 0,56 & 73,3 \\
\hline
\end{tabular}

Tablo 2. Temalar ve alt temalar.

\begin{tabular}{l|l}
\hline \multicolumn{1}{c}{ Ana Temalar } & Alt Temalar \\
\hline 1.Bireysel Boyut & $\begin{array}{l}\text { 1.1.Kısıtlılıklar: Su, Tuz ve Diyet Değişiklikleri, } \\
\text { 1.2.Yorgunluk ve Diğer Komplikasyonlar (Kan Basıncı Değişiklikleri, Baş Ağrısı, Baş } \\
\text { Dönmesi, Halsizlik), } \\
\text { 1.3.Psikolojik Zorluklar/Bağımlılık Duygusu } \\
\text { 1.4. Baş Etme Deneyimleri / Destek Alma Gereksinimi, }\end{array}$ \\
$\begin{array}{l}\text { 2.Aile Ve Sosyal Çevre } \\
\text { Boyutu }\end{array}$ & $\begin{array}{l}\text { 2.1.Eş ve Aile İlişkilerinde Değişiklikler } \\
\text { 2.3.Eknırlı Sosyal Çevre }\end{array}$ \\
\hline 3.Kurumsal Boyut & $\begin{array}{l}\text { 3.1.Kurum Deneyimlerine İlişkin Zorluklar } \\
\text { 3.2.Ekiple İletişim }\end{array}$ \\
\hline
\end{tabular}

\subsection{Alt Tema: Kisitlılıklar: Su, Tuz ve Diyet Değişiklikleri}

Hastaların pek çoğu ilk olarak yaşadıkları kısitlılıkları dile getirmişlerdir. Su ve tuz kısıtlaması ile diyet değişikliklerine uyma zorunluluğunun yaşamlarında ciddi kısıtlanma duygusuna neden olduğunu ifade etmişlerdir. Hastalar az su içmekten, istedikleri şekilde yemek yiyememekten dolayı rahatsılık hissetmektedirler.

"Her şeyim kusitll, kahve içmem, çay içmem, turşu falan yiyemem, hep senelerden beri tuzsuz yerim” K2, K4, K13

"Çok kisitlamalarımız oluyor. Mecburuz kisitlamaya” $K 7$

"Diyette yediklerimize dikkat etmemiz çok önemli, mümkün olduğunca yememeye çalışırım” K9, K11,K12
"Evde mümkün olduğu kadar tuzsuz yiyorum, ama dışarı çıtıtı̆̆ıızda onu kisitlamak pek mümkün değil" K10

\subsection{Alt Tema: Yorgunluk ve Diğer komplikasyonlar (kan basıncı değişiklikleri, baş ağrısı, baş dönmesi, halsizlik)}

Katılımcılar, HD uygulamasının yapıldığı gün işlemden sonrasında belirgin şekilde yorgunluk yaşadıklarını, o gün içinde yorgunluk nedeni ile dinlenme ihtiyaçlarının olduğunu ve ancak ertesi sabah normal yaşamlarına döndüklerini ifade etmişlerdir.

"Diyalizden çıkınca tansiyon değişikliklerim oluyor, baş dönmelerim oluyor” $K 1, K 2, K 5$

"Diyalizden çıktı̆̆ımda hep yorgun oluyorum” $K 1, K 4, K 7, K 9, K 11$ 
"Yorgunluk sadece diyaliz günlerinde, diyaliz çıkışında da oluyor” $K 3, K 7$

"Buradan çıkarken TA değişikliğim oluyor, eskiden daha fazla oluyordu” K8, K9,K10

"Onlarla beraber yürüyüş yapmak istiyorsunuz, oynamak, oyalanmak istiyorsunuz ama enerjiniz yetmiyor, onlara (çocuklara) ayak uydurmak sorun oluyor. \%50 enerjiniz düşüyor" K12

"HD giriyor olmak insanı yoruyor, komplikasyonlardan dolayl ăğr bir yük oluyor" K13

"Fiziksel olarak yorgunluk, TA değişikliklerim oluyor, çok hızlı düşüp yükselebiliyor" K14

\subsection{Alt Tema: Psikolojik Zorluklar/Bağımlılık Duygusu}

HD tedavisi alan kronik böbrek hastaları, psikolojik zorlanma hissini, hastalığın ve tedavinin ilk aylarında çok yoğun yaşadıklarını belirtmişlerdir. Kendilerini en zorlayan duygunun bağımlılık duygusu olduğunu ifade etmişlerdir.

“En büyük şey özgürlüğ̈̈nüzü bağlayıcı bir şey” K1, K5, K11, K13

“Bu hastalı özgürlüğ̈̈mü klsitllyor, belli günlerde, belli saatlerde belli bir yerde olma zorunluluğum var, $K 1, K 2, K 7, K 10$

“Bir tek buraya bağll olmak...” K3

"Normal insan gibi değiliz tabii, haftada 3 gün buraya bağlanıyorsun, mecbursun buraya geleceksin yani” $K 7, K 8$,

\subsection{Alt Tema: Baş Etme Deneyimleri/Destek Alma Gereksinimi}

Hastalar ilk birkaç ay çok zorluk ve belirsizlik yaşadıklarını ifade etmişlerdir. $\mathrm{Bu}$ süreçte hastaların bireysel farklılıkları da önemli olmuştur.

"Yani umudunu kaybetmek gibi bir lüksüm yok, lüksü olmamalı insanın. Tabi ki çok dibe düştüğ̈̈m zamanlar olmadı mı oluyor. Ama toparlaniyor insan zamanla”, " Tabiî ki destek aldım, almam gerekiyordu, çok ciddi ataklarım oldu, imkansizdı desteksiz atlatmak. Destek aldım” K4
"Sonuçta sorumluluklarımız var, aileniz var mecbursunuz bunlara alışmaya” K5, K8

"Ben çok inançlı bir insanım Allah verdi, benim kaderim böyle çekicem." $\mathrm{K} 9$

"HD girmeye başladı̆̆ım dönemlerde psikolojik olarak destek alma ihtiyacım oldu”, K9

"Psikolojik destek aldim öyle dayanabiliyorum, hastane süreci çok sıkıntılı geçti” K13

"Hayat her şeye rağmen güzel nefes almak güzel.” K15

\section{Tema: Aile ve Sosyal Çevre Boyutu}

Katılımcıların ifadelerinden oluşturulan diğer tema,aile ve sosyal çevresinde yaşadığ deneyimler ve ilgili alt temalardır. Alt temalar; eş ve aile ilişkilerinde yaşanan değişiklikler, sınırlı sosyal çevre ve ekonomik boyuttur.

\subsection{Alt Tema: Eş ve Aile İlişkilerinde Değişiklikler}

Katılımcıların pek çoğu evli bireylerden oluşmaktadır. Hastalık ve tedavi süreçlerinde bireyler eş desteğini çok önemli bulduklarını ifade etmişlerdir.

“Eşim sağ olsun çok anlayışlı” K2, K13, K14

"Erkek arkadaşım var, bu durum herhangi bir sorum olmuyor, sonuçta bu sağllklı bir bireyinde her an başına gelebilir. Arkadaşım mantıksız, anlayışsız bir insan değil" "Hem eğitim hem manevi konuda ailem tam destek" K4

"Eşim çok anlayışl, özverili ve bana en büyük destek, hakkını inkar edemem.

ama siz ortama uyum sağlayamiyorsunuz, kisitlılıklarını nedeniyle..." K12

"Annem bana çok düşkün ve bana çok destek" K15

\subsection{Alt Tema: Sınırlı Sosyal Çevre}

Hastalar, arkadaş ilişkilerini sürdürmede zorlanma, ayak uyduramama, zaman kısitlılıkları nedenleri ile sosyal çevrelerinde daralma yaşamaktadırlar. Katılımcılardan biri ergenlik döneminde olan çocuklarının ev dışında birlikte vakit geçirme isteklerine uymak zorunda kaldığında, dişarıda 
kısitlılıklara uymada zorlandığını ifade etmiştir.

"Komşularım çok iyidir, kardeşlerim ararlar, sorarlar" $K 7$

"Sosyal anlamda misafirliğe gittiğinizde yemek içmek paylaşım sorun oluyor, örneğin misafirliğe gittiğinizde sorun oluyor, her zaman hoş olmuyor" K12

"Mesela arkadaşlarımla görüşemiyorum, çünkü günümü HD de geçiriyorum. Ertesi gün de dinlenmekle geçiyor" K14

"Ben gezmeyi çok seven bir insandım, ama ampüte olduğumdan beri bunlar yapamiyorum" K15

\subsection{Alt Tema: Ekonomik Boyut (İş Kaybı, İş Değişikliği)}

Katılımcıların pekçoğumeslekleri ve ekonomik şartlarındaki farklılıktan kaynaklanan çeşitli seviyelerde ekonomik zorlanmalar yaşadıklarını belirtmişılerdir.

"Bu hastalık başlayalı işe gitmiyorum, ekonomik anlamda yükümüz arttı tabii" K2, K10

"HD hastası olmak özel yaşantından çok iş hayatına etkisi oldu, ben bu yüzden iyi yerlerde çok firsatlar kaçırdım. Yani tek şansim devlet olmast şu anda” $K 4$

"Ben bir kamu kurumunda diş teknisyeni olarak çalıştığım için buraya gelmek benim için izin anlaminda sorun olmuyor ama ĕger özelde çalışsaydım, böyle olmazdı" K9

"Çalışma düzenin olamıyor, iş hayatın bitiyor, devlet memuru olmayanlar için durum çok zor" K14

\section{Tema: Kurumsal Boyut}

Kat1lımc1lar sosyal güvencelerinden dolay1 aldıkları hizmetten dolayı memnun olmalarına karşın, farklı kurum deneyimleri yaşadıklarında zorlandıklarını, bürokratik işlemlerin kendileri için yorucu, vakit alıcı ve gereksiz olduğunu belirtmişlerdir.

\subsection{Alt Tema: Kurum Deneyimlerine İlişkin Zorluklar}

Hastalar zaman içinde yaşadıkları yerler değiştikçe veya yer değiştirmek zorunda kaldıklarında farklı kurumlardan hizmet alma deneyimi yaşadıklarından kurumlar arasındaki farklılıkları, kendileri açısından değerlendirmiş̧lerdir.

"Gittiğim yerlerde HD merkezi aramak zorundayım” $K 1, K 7$

"Buranın servisi yok, bizim için zor oluyor" $K 2, K 3$

"Başka yerlerde tedavi tercihim değil, çok aşırı zorunlu olmadıkça, çünkü özel merkezlerde buradaki tedavi gibi olmuyor" K4, K7, K9, K13

"İki bacağım ampüte, akülü araba kullanmiyorum, tekerlekli sandalye kullanıyorum, uzun süreli istemiyorum daha çok protez istiyorum akülü arabayı oturduğum yerde koyacak imkanım yok" K15

\subsection{Alt Tema: Ekiple iletişim}

Katılımcılar tedavi süreçlerini etkileyen bir diğer alt tema olarak sağlık ekibi ile sürdürülen iletişimin önemini ifade etmiştir.

"Özel merkezlerde buradaki tedavi gibi olmuyor. Hem makine, hem hemşiremiz açısından gerçekten çok kaliteliler" $K 4$

"Kalp hastasiyım ben burada kendimi daha güvende hissediyorum. Çok memnunum burada bakımdan, hemşirelerimizden Burdan çok memnunum ama gelip gitmek zor" K7

"Buradaki bakımdan özellikle baş hemşireden son derece memnunum. Allah razl olsun. Ekip çok iyi ve anlayışl burada olmak güven veriyor" $K 9$

\section{Tartışma}

Çalışmada, HD tedavisi alan kronik böbrek yetmezliği hastalarının temel olarak sorunlarının üç boyut altında yapılandığ belirlenmiștir. İlk boyut "Bireysel boyut" olarak saptanmıştır. KBY yaygın sistemik etkilere neden olan bir hastalıktır. Bireysel boyut başlığı altında hastanın fiziksel ve psikolojik sorunlarının yer aldığı görülmüştür. Bunların başında; sıvı ve tuz tüketimindeki ciddi kisitliliklar, diyete uyumda zorlanma, psikolojik olarak bağımlılık duygusunu kabul etmede zorlanma, baş etme deneyimleri yer almaktadır. Çalışmanın sonuçları literatür ile uyumlu görülmektedir. Diyet ve siv1 kısıtlılıkları diyalizdeki hasta için en zor 
tedavi rejimidir. ${ }^{14}$ Theofilou, HD giren hastaların genellikle yiyecek ve sıv1 kısıtlaması, kaşıntı ve enerji düşüklüğü gibi fiziksel sorunlara maruz kaldıklarını çalışmasında belirlemiştir. ${ }^{5}$

Çalışmamızda katılımcıların çoğu diyetleri konusunda eş ve aile üyelerinden tam destek aldıklarını belirtmişlerdir. Yapılan bir çalışmada, evli olan hastaların bu kisitlıliklarda daha iyi destek aldıklar1 belirlenmiştir. Düşük sosyal desteğe sahip evli hastaların bu kisitliliklara uyum konusunda daha çok zorlandikları belirtilmektedir. ${ }^{14}$

Clarkson ve Robinson, hastaların yaşam deneyimlerini inceledikleri çalışmada, 5 kategori belirlemişlerdir. İlk grupta, yaşam k1sitlılıklar1; sinırlı seyahat, siv1 ve diyet kısıtlılıkları, sinırlı gelir, fazla tıbbi destek ihtiyacıdır. İkinci grupta; diyaliz işleminin yarattı̆g1 sinırlılıklar olan; planların ertelenmesi, sınırlı sosyal yaşam, aktivite yokluğu, zaman kaybı, diğerlerine bağımlı olma durumu paylaşılmıştır. İfade edilen kısitlamaların içinde evlenme planları, ev satın alma planları için beklemeler de yer almaktadır. Üçüncü kategoride; beden, zihin ve manevi değişikliklerden; depresyon, enerjik olmama, güçsüzlük ve yorgunluk yer almıştır. Dördüncü kategori; baş etmeye yarayan, hastaları motive eden tutumlar ile destek olan tüm kişi ve uygulamalar ifade edilmiştir. Aile, arkadaşlar, sosyal grup, dini uygulamalar (Tanriya yönelme, kiliseye gitme, dua etme), desteklenme ve baş etmede yer almaktadır. Beşinci kategoride HD hastaları eksiklik yaşadıkları alanlar olarak; sağlık yönetimi konusunda hasta ve bakım verenlerin değişiklikler konusunda bilgilendirilmesi ve desteklenmesi ihtiyacından bahsetmişlerdir. ${ }^{8}$

Çalışmada, katılımcılar en sık yaşadıkları diğer sorunlar olarak, yorgunluk ve bazı komplikasyonları ifade etmişlerdir. Hastaların yaşadıkları bu progresif sürecin, tedavi ve bunlara bağlı ek komplikasyonların gelişmesi beklenen bir sonuçtur. Hastalığa eşlik eden yorgunluğun düzeyi fiziksel, psikolojik ve durumsal faktörlerle ilişskilidir. Yorulmaz ve arkadaşları, diyaliz sırasında hastaların \%32,9'unda, diyalizden sonra \%72,3'ünde yorgunluk yaşandığını saptamışlardır. ${ }^{15}$ Diyaliz tedavisi sırasında kan akımındaki hızlı değişiklikler, volüm azalması/artması durumlarında kan basincinda dalgalanmalar görülmektedir. Uzun süreli devam eden HD uygulamaları sonucunda zamanla gelişen kalp yetmezliği kan basıncının yüklenmesine neden olan bir diğer sorundur. ${ }^{16}$ Küçük ve Demir yaptıkları çalışmada, HD hastalarının \% 58,6'sında böbrek yetmezliğine eşlik eden hastalıklar bildirilmiştir, bunlardan en sik olan $\%$ 33,6 ile hipertansiyondur. ${ }^{17}$

Katılımcıların hemen hepsi, bir işleme (HD) bağımlı yaşamaktan oldukça memnuniyetsiz durumdadırlar. Hemodiyaliz uygulamas1 hastaneye yatmay1 gerektirmeyen bir tedavi olmasına rağmen hastalar, hastaneye gelmeye bağlı yaşadıkları sürekli kontrol duygusu nedeniyle uyum sorunu yaşıyor olabilirler.

Kronik hastalığ 1 olan bireyler, farklı düzeylerde olabilen, günlük yaşam gereksinimlerinin karşılanması, beslenme, uyku, çalışma düzeninin sürdürülmesi, iletişim gibi konularda desteklenmeye gereksinim duyabilirler. Bu durum hastalarda bir yakınına veya sağlık personeline bağımlılık duygusunu arttırmaktadır. Hasta sürece bağlı olarak bu durumdan rahatsızlık duyabilir. ${ }^{18}$ Kronik hastalıklar arasında, diyaliz hastalarının kuruma bağımlılıkları en yüksek seviyededir. ${ }^{17}$

HD ve Periton diyaliz (PD) hastalarının ruhsal durumları ile yaşam kaliteleri arasındaki ilişkide sağlık inançlarının etkisi incelenmiş, kişisel kontrol duygusu yüksek olan hastaların daha düşük bir duygusal tepki verdikleri ve hastalığ gösterilmiştir. ${ }^{5}$ Tedaviye uyumsuzluk, bir dizi klinik soruna ve dolayısı ile düşük yaşam kalitesine neden olmaktadır. Diyaliz hastalarının çoğunun kasitlı veya kasitlı olmasa da tedaviye tam olarak uymadiğ 1 düşünülmektedir. ${ }^{8}$

KBY hastalarının yaşam kalitelerinin düşük olduğu ve karşılanmayan manevi ihtiyaçları olduğu saptanmıştır. Hastaların varoluşsal inançlarının olması, hastalık deneyimine ilişkin bir açıklama getirdiğinden dolayı uyumlarına olumlu etki yapabilir. ${ }^{19} \mathrm{HD}$ 
hastalarının uyumsuzluklarından sorumlu pek çok neden bulunmaktadır. Bunlar hastalık hakkında yetersiz eğitim ve öngörülemeyen bir kronik hastalık üzerinde daha fazla kontrol sahibi olma istekleridir. ${ }^{8}$

Hastalar ilk tanı ve tedavi dönemlerini atlattıktan sonra, genellikle kendilerini daha rahat hissettiklerini belirtmişlerdir. Bunun nedeni, herkesin, hastallk ve tedavi gibi yaşamlarında gelişen her değişikliğe yönelik bir uyum süresine ihtiyacı olduğu, bireysel farklılıklar, eğitim düzeyi, kişilik yapısı farklılıklarının bunları etkilediği düşünülmektedir. Katılımcılar, bireysel farklilıklardan kaynaklanan nedenlerden dolayı destek alma ihtiyaçları olduğunu veya bundan kaçındıklarını belirtmişlerdir. Çalışmada, hastaların çoğu tarafindan destek alma ihtiyac1 ve deneyimi olduğu ifade edilmiştir. Özellikle ilk HD tedavisini izleyen birkaç ay içinde bu ihtiyacın çok fazla olduğu vurgulanmıştır.

Kronik böbrek hastaları, hastalığa uyum konusunda çeşitli zorluklar tanımlamışlardır: bunlar hayatta kalmak için diyalize bağlı olmak, fiziksel, sosyal ve aile rollerini sürdürmede zorlanma ve sonuç olarak kendilik kavramlarında bir tehdit algıs1 hissedilmesidir. ${ }^{19}$

Özkaraman ve ark. HD hastalarının sağlıklı yaşam biçimi davranışları üzerine yaptıkları çalışmada, erkeklerin fiziksel aktivite, beslenme ve stres yönetimi puanlarının kadınlardan yüksek, bekar hastaların, evli olanlara göre fiziksel aktivite, beslenme, manevi gelişim ve stres yönetimi puanlarının daha düşük olduğunu saptamışlardır. ${ }^{20}$ Diğer bazı kronik hastalığı (romatoid artrit, ülseratif kolit gibi.) olan bireylerde de benzer kisitlilık duygularının yaşandığı gösterilmiştir. ${ }^{21}$

"İç sağlık inancı" olarak ifade edilen ve hastalığın kontrolünde hastanın etkin olduğu düşüncesini kabul eden yaklaşımın, HD hastalarında daha yaygın olduğu gösterilmiştir. HD ve PD hastalarının, sağlık inançlarına ilişkin çalışmada, HD hastalarının, sağlık durumlarını düzenlemek için, kendi sağlık durumları üzerindeki kontrollerine daha fazla odaklanmayı tercih ettikleri ve bu durumun HD hastalarının daha az somatik belirtiler, sosyal işlev bozukluğu ve şiddetli depresyon durumlarını daha iyi değerlendirmelerine yardımcı olduğu gösterilmiştir. ${ }^{5}$ Diğer bir çalışmada, HD hastalarının sağlık durumlarını düzenlemek için kendi kişisel kontrollerine daha fazla odaklanarak, iç boyut kontrolünü daha fazla tercih ettikleri gösterilmiştir. ${ }^{22}$

Pek çok HD hastası diyet ve sıv1 kısıtlamalarına uyma ve davranışlarını buna göre değiştirme konusunda "nasıl kaçamak" yapabileceklerinin (diyetin sinırlarını nasıl ve ne kadar zorlayabilecekleri, esnetebileceklerinin) farkındalığına sahiptir. $\mathrm{Bu}$ davranış tarzı (belki başa çıkma tarzı) iç kontrol ve ustalık algısinı artıran ve benlik saygısını güçlendiren psikolojik bir faydaya sahip olabilir. ${ }^{8}$

Diyaliz tedavisi hastaların yaşamlarında ciddi değişikliklere neden olur. Fiziksel sorunlara ek olarak hastalar, psikolojik ve ekonomik sorunlara maruz kalırlar. Diyaliz tedavisi başladiktan sonraki ilk y1l içinde herhangi bir nedenle hastaların \%70 oranında psikiyatrik desteğe ihtiyaç duydukları gösterilmiştir. ${ }^{16}$ Yapılan bir meta analizde, kronik bir hastalığ 1 olan depresif bireylerin, tedaviye uymama eğilimleri üç kat daha fazla bulunmuştur. Diyaliz hastaları psikososyal adaptasyon konusunda desteklenmelidir. ${ }^{8}$ Hastalar psikolojik olarak stres, benlik algısında bozulma, öz saygisinda azalma, gelecekle ilgili belirsizlik, endişe, aile üyelerine karşı suçluluk duygusu yaşamaktadırlar. ${ }^{5} \quad$ Yaşam kalitelerindeki bozulma özellikle uzun süreli HD hasta grubunda belirgin olarak düşük bulunmuştur. HD ve PD hastaları ile yapılan bir çalışmada, tedavinin ilk aşamalarındaki farklılıklara odaklanan HD hastalarının daha fazla endişe, uyku sorunları, depresyon veya intihar düşüncesi semptomları yaşadıkları bildirilmiştir. ${ }^{22}$ Diyaliz davranışlarını ve fizyolojik önlemleri atlamak veya kısaltmak olarak ifade edilen uyumsuzluk, klinik faktörlerin yanısıra daha fazla depresyon belirtileri ile ilişkili bulunmuştur. Depresyon diyaliz hastalarında sık görülen, son dönem böbrek hastalarında mortalite ile de ilişkilidir. ${ }^{8}$ 
Kronik hastalıkların yönetiminin planlanmasında, hastaların baş etme deneyimleri tanımlanmaya çalışılmalı, gerek duyulan, yetersiz olduğu düşünülen konularda, hastalara destek, danışmanlık verilmelidir. Hastalara özel yaklaşımlarda, bireysel farklılıkları, kişilik ve aile yapıları mümkün olabildiğince dikkate alınmalıdır.

Çalışmada belirlenen bir diğer tema; Aile ve Sosyal Çevre Boyutudur. HD tedavisi alan hastalar ve aileleri farklı sorunlara maruz kalırlar. Kronik hastalar bu süreci yakın çevreleriyle birlikte deneyimlerler. Hasta ve ailenin, ilişkilerinin sağlamlığı, rollerin dağılımı, değişikliklerin kompanse edilebilmesi ve aile tipi, hastalığa tepkimeleri şekillendirir. Çalışmamızda, hastalar aile içi sorun yaşanma potansiyelinin olduğu ancak iyi aile ilişkileri sayesinde bunlarla baş edebildiklerini belirtmişlerdir.

Katılımcıların çoğu, eş ve aile desteğini yeterli bulmaktadırlar. $\mathrm{Bu}$ durum, kültürel yapımızda insanlarımızın hastalığa çoğu zaman kaderci bir yaklaşımla bakması, hastalıklarını "manevi bir sınav" olarak algıladıkları ve inançları gereği daha kolay kabullenmeye yatkın oldukları şeklinde yorumlanabilir. Aile desteği bazı hastalar için çok olumlu olmakla beraber hastalar aile üyelerine verdikleri yük duygusundan zaman zaman rahatsızlık da hissedebilmektedirler. Hastalar yakınlarından gördükleri ilgi ve destekten memnun olmakla beraber zorunlu olmadıkça onlardan yardım talep etmekten çekinmektedirler.

Hemodiyaliz

hastalarının uyumsuzluklarından sorumlu nedenler arasında, aile desteğinin eksikliği ve tedavi rejimlerinin karmaşıklığı da yer almaktadır. Düşük sosyal desteğin depresyon ve ölümle ilişkili olduğu gösterilmiştir. ${ }^{8}$ Başka bir çalışmada, HD hastalarının özel günlerde dahi kuruma gelmek zorunda olmaktan çok mutsuz oldukları ve bu durumun aileleri ile birlikte olabilecekleri zamanı sınırladığını belirtmişlerdir. $^{21}$

HD'e giren hastalar, normal koşullarda, haftanın en az 2-3 gününü ve günün büyük bir kısmını klinikte geçirmek zorundadırlar. $\mathrm{Bu}$ süre bir kişinin yaşamında oldukça uzun bir süredir. Hastaların yaşamında ciddi kısitlilikları da beraberinde getirir. Bu durum, bireyin gün içinde etkinliklerden uzak kalmasına, resmi kurumlardaki işleri yürütmede zaman kısitlaması, sosyal ve özel ilişkilere ayrılacak zamanın daralmasına neden olmaktadır. Çalışmamızda hastaların bazıları, yeme içme kısıtlılıklarından dolayı aileleri ile olmayı tercih ettiklerini, yeni ve farklı bir sosyal ortama katılmaktan (dışarıda yemek yemek, misafirliğe gitmek vb.) kaçındıklarını belirtmişlerdir. Hastalar, bazen yakınlarına ayak uydurmakta sorun yaşamaktadırlar. $\mathrm{Bu}$ durum onların sosyal çevrelerinin sınırlanması sonucuna neden olmuş olabilir.

Yaşam şekli sınırlılıkları, hastaların sosyal yaşamlarını ciddi oranda kısıtlamaktadır. $\mathrm{Bu}$ kısıtlılıklar hastaların inançlarını, kaygı ve depresyona yol açan kişisel kontrol hissini, baş etme davranışlarını olumsuz etkileyebilmektedir. ${ }^{23,24}$

Kisıtlılıklardan kaçınılamayacağını düşünen hastalar, bunu kendilerine hatırlatan ortamlardan (davete gitmek, dans etmek gibi) uzak kalmaya çalıştıklarını ifade etmişlerdir. Hastaların pek çoğu daha önceden yapmakta sorun yaşamadıkları şeyleri yaparken (çocuğu okula birakmak veya almak) şimdi bu işleri sürdürmede sıkıntı yaşadıklarını ve bu durumun aile içi rollerini yerine getirmelerine engel olduğunu belirtmişlerdir. ${ }^{8}$

Çalışmamızda hastaların bir kısmının ekonomik sıkıntılar yaşadıkları saptanmıştır. $\mathrm{Bu}$ durumun nedeni bireysel faktörlere göre farklılık göstermektedir. Özel kurumlarda çalışan hastalar, HD uygulaması nedeni ile işten ayrılmak zorunda kalmakta olduklarını belirtmişlerdir. Kendi iş yeri olan hastalar çalışma saatlerini esnek tutabilmelerine karşın, işin başında olmamaktan kaynaklanan ve hatta iş yeri kapatma ile sonuçlanan ekonomik zorlanmalar yaşamaktadırlar. Resmi kurumlarda çalışma imkânı olan hastalar diğer hastalara göre daha rahat olduklarını belirtmişlerdir. Bunun nedeni kurumun hastalık ve tedavi zamanına onay vermesi, hastaların daha hafif iş olanaklarından yararlandırılmaya çalışılması olabilir. 
Hastaların 2/3 böbrek yetmezliği tanıs1 aldıktan sonra önceki işlerine dönememektedirler. Eğitim düzeyi yüksek olan veya iş yeri resmi kurum olan bireylerin işe dönmeleri daha kolay olabilmektedir. ${ }^{16}$ Yapılan bir çalışmada HD giren 194 hastanın \%79,9'unun çalışamadıkları belirlenmiştir. ${ }^{24}$ Diyalizdeki birçok hasta, günlük yaşam aktivitelerinde ulaşım ve diğer bakım ihtiyaçlarını sürdürmede başkalarına güvenme ihtiyacında olduklarını belirtmişlerdir. ${ }^{8}$ Hastalar bakım verenlere karşı suçluluk da duyabilirler. Bazı hasta yakınları, işten ayrilmalarından hastalarını sorumlu tutmaktadırlar. ${ }^{21}$

Çalışmanın son teması; Kurumsal Boyut olarak belirlenmiştir. Hastaların sürekli ilişki halinde oldukları kurumlarla sorunlarının olması beklenen bir durumdur. Ülkemizde, HD uygulaması sağlık sistemi tarafindan giderleri karşılanan bir uygulamadır ve bu hizmet özel veya resmi kurumlardan karşılanabilir. Çalışmamızda hem özel hem de resmi kurumlarda HD tedavisi almış hastaların deneyimleri göstermiştir ki, hastalar resmi kurumdan hizmet aliyor olmaktan son derece memnundurlar. Gittikleri her yerde (yazlıkta) aynı kalitede bakım alabilecekleri bir merkezin olmaması, kuruma ulaşım desteğinin olmaması en temel iki sorundur.

HD hastaları diyaliz merkezine yakın olmak zorunluluğunun kendileri için bağlayıcı bir durum olduğunu ifade etmişlerdir. ${ }^{21}$ Günümüzde sağlık bakım kalitesinin artmasına bağlı olarak, hastalar daha bilinçli ve haklarının farkındadırlar. Bu durum resmi veya özel kurumlar arasında rekabeti teşvik eden bir duruma dönüşebilmektedir. Bunun sonucu olarak, sağlık hizmeti sağlayıcıları için hizmet kalitesi ve hasta tatmini konuları kritik önemli konular haline gelmektedir. ${ }^{6}$

Kurumdaki iletişim, bakım kalitesini doğrudan etkileyen bir parametredir. Çalışmadaki katılımcılar, ekiple iletişimi, ekibe güven duymayı çok önemsediklerini ifade etmişlerdir. Katılımcılar, üniversite hastanesinde HD almaktan oldukça memnun olmalarının nedenleri olarak; resmi kurumlardaki sağlık ekip ve ekipmanlarının fazla olmasından kaynaklanan güven ve HD tedavi sürelerinde kisitlama yapılmamasını belirtmişlerdir. Çalışmada, HD tedavisine başlama süreleri 1-22 y1l arasında değişen hastaların, kurum, hekim ve hemşire bakım memnuniyetleri çok yüksektir. Özellikle uyumlu ekip dinamiğinden dolayı kuruma güvenleri de fazladır. Birimdeki lider hemşirenin, ekipteki tüm hemşirelerle olan uyumu ve her hastanın övgü içeren ifadeleri ekibin uyumunu açıklayan bir durumdur.

HD merkezlerinde çalışan personelin, hastalığa ve tedavi sürecine ilişkin bilgi eksikliği, kibar ve nazik olmaması, hastaların kendilerini kurumda güvende hissetmemelerine neden olmaktadır. ${ }^{17}$

Hemodiyaliz hemşireliği, hasta bakımının, izleminin çok yoğun olabildiği bir uygulama alanıdır. Çok yönlü sorumlulukların üstesinden gelebilmesi için iyi bir eğitimden geçmiş olması, temel birçok beceriyi gösterebiliyor olması gerekmektedir. Hemşireler mesleğin ve sağlığın gelişmesine katk1 sağlayacak nitelikli, bilimsel ve güvenilir çalışmaları yapma sorumluluğu taşımaktadırlar. $^{24}$

Hastaların teknolojik verileri desteklediği anlaşılan, kendileri hakkındaki gözlemlerine gereken değerin tekrardan verilmesi, hastaların tedavi rejimine uyumlarını destekleyebilir. ${ }^{25}$

Araştırmanın tek bir merkezde yürütülmüş olması sinırlılığıdır.

\section{Sonuç}

Diyalizle yaşayan hastaların yaşantılarına ilişkin yeterli kalitatif çalışma sayısı sınırlıdır. Çalışmanın planlanmasında ve araştırma tasarımının seçiminde bu bilgilerden yola çıkılmıştır.

Çalışma sonuçları her hastanın bu süreçten kesinlikle etkilendiği, bu etkilerin bireysel özelliklerle ilişkili olarak değişiklik göstermekle beraber bazı ortak sorunlarda fikir birliği gösterdiği saptanmıştır. Bu ortak görüşlerden üç temaya varılmıştır.

Alanda yapılacak yeni çalışmalara ihtiyaç bulunmaktadır. Buna ek olarak hastalar, diyet ve sıvı kısıtlamaları, ilaca bağlı olma ve böbrek replasman tedavisi gibi konularda da uyum eğitimine alınmalıdırlar. Hastalara 
verilecek bakımın kaliteli ve istenen düzeyde planlanması ve uygulanması açısından çalışma sonuçlarının klinikte çalışanlara ve araştırmacılara yarar sağlayacağ 1 ve yön verebileceği ön görülmektedir.

\section{Araştırmanın Etik Yönü}

Araştırma için, İlgili Üniversitenin Bilimsel Araştırma ve Yayın Etiği Kuruluna başvurulmuştur. Etik kurul tarafindan gerekli izin (23-2017) alınmış olan çalışma, Helsinki İlkeler Deklerasyonuna uygun olarak yürütülmüştür. Araştırmanın yürütüleceği klinikten yazılı izinler alınmıştır.

\section{Bilgilendirilmiş Onam}

Katılımcılara araştırma öncesinde açıklayıcı bilgilendirme yapıldıktan sonra sözlü ve yazılı onamları alınmıştır.

\section{Yazar Katkıları}

Yazarlar çalışmaya eşit düzeyde katk1 sağlamışlardır.

\section{Teșekkürler}

Araştırmaya katılmayı kabul eden tüm katılımcılara içten paylaşımları için teşekkür ederiz.

\section{Çıkar Çatışması Beyanı}

Yazarların herhangi bir çıkar çatışması bulunmamaktadır.

\section{Araştırma Desteği}

Çalışmayı maddi olarak destekleyen kişi/kuruluş yoktur.

\section{Beyanlar}

Çalışma daha önce herhangi bir yerde sunulmamıştır.

\section{Kaynaklar}

1. Dönmez ÇF, Yılmaz M. Diyaliz Hastaları ile Nefroloji Hemşireleri İçin Ölüm Kavramının Anlamı ve Ölümle Baş Etmede Nefroloji Hemşiresinin Rolü. Psikiyatri Hemşireliği Dergisi - Journal of Psychiatric Nursing. 2012; 3(3):141-147.

2. Başaran D, Şahin Altun, Ö, Kaban F. Ecder T. Hemodiyaliz Hastalarının Umutsuzluk Düzeylerinin Değerlendirilmesi. Nefroloji Hemşireliği Dergisi. 2016 1. Sayı, 9-16

3 . https://hsgm.saglik.gov.tr/tr/kronikhastaliklar-haberler/turkiyebobrek-hastaliklari-onleme-ve-kontrol-programi-2018-

2023.html_(Erişim Tarihi: Aralık, 2019).

4. Taner Gürsoy Ş, Türk Soyer M, Çiçeklioğlu M. Ege Üniversitesi Tıp Fakültesi (EÜTF) Hemodiyaliz Hastalarında Sağkalım Çözümlemesi, Ege Tıp Dergisi. 2005; 44 ( 3 ) : 155 160.

5. Theofilou P. Quality of Life And Mental Health In Hemodialysis And Peritoneal Dialysis Patients: The Role Of
Health Beliefs. Int Urol Nephrol. 2012; 44:245-253. DOI 10.1007/s11255-011-9975-0.

6. Meriç M, Oflaz F. Hemodiyaliz Hastası Olan Bir Eşle Yaşamak: Eşlerin Yaşamlarındaki Gelgitler. Psikiyatri Hemşireliği Dergisi. 2013; 4(1):21-26. Doi: 10.5505/phd.2013.96268.

7. Yılmaz Karabulutlu E, Okanlı A. Hemodiyaliz Hastalarında Hastalık Algısının Değerlendirilmesi, Anadolu Hemşirelik ve Sağllk Bilimleri Dergisi. 2011; 14(4): 25-31.

8. Clarkson KA, Robinson K. Life on Dialysis: A Lived Experience, Nephrology Nursing Journal. January-February 2010; 37(1): 29-35.

9. Gürbüz S, Şahin F. Sosyal Bilimlerde Araştırma Yöntemleri. 5. Baskı, Seçkin Yayıncılık. 2018. 407-436.

10. Creswell JW. Nitel Araştırma Yöntemleri. 3. Baskıdan çeviri, Siyasal Kitabevi. Çeviri editörleri: Bütün M, Demir. 2018; 7783.

11. Baltacı A. Nitel Araştırmalarda Örnekleme Yöntemleri ve Örnek Hacmi Sorunsalı Üzerine Kavramsal Bir İnceleme, Bitlis Eren Üniversitesi Sosyal Bilimler Enstitüsü Dergisi/Journal of Bitlis Eren University. 2018; 7(1): 231-274.

12. Dağhan G. Kitap İncelemesi, (Tashakkorı A, Teddlıe - SAGE Handbook of Mixed Methods in Social \& Behavioral Research) (2nd EditionElementary Education Online.) 2015; 14(1), 1-6. C. DOI: 10.17051/io.2015.07705

13. Maxwell JA. Nitel Araştırma Tasarımı, 3. Baskıdan çeviri. Nobel Yayıncılık, Çeviri Editörü: Çevikbaş M.

14. Graneheim UH, Lundman B. Qualitative Content Analysis In Nursing Research: Concepts, Procedures And Measures To Achieve Trustworthiness. Nurse Educ Today. 2004; Feb; 24 (2):105-12.

15. Yorulmaz H, Karahaliloğlu N, Kürtünlü N, Türkyılmaz Ç, Hacıoğlu N. Kronik Böbrek Yetmezliği Olan Hastalarda Yorgunluğa Etki Eden Faktörlerin Değerlendirilmesi. Nöropsikiyatri Arşivi. 2011; 48(1):59-65.

16. Akpolat T, Utaş C. Hemodiyaliz Hastasında Sık Karşılaşılan Sorunlar, 2019; Konu:27. 1-26. http://www.nefroloji.org.tr/folders/file/hemodiyaliz_hastasinda karsilasilan_sorunlar.pdf (Erișim tarihi: 08.07.2019).

17. Küçük M, Demir S. Hemodiyaliz Hastalarının Yaşam Kaliteleri, Hasta Özellikleri Ve Hemşirelik Hizmetleri İle İlgili Doyumları Arasındaki İlişkinin İncelenmesi. Afyon Kocatepe Üniversitesi Sağlık Bilimleri Enstitüsü, YL Tezi. 2008; Tez No: 2008-005.

18. Kaya Akı M, Demir Dikmen Y. Hemodiyaliz Hastalarına Primer Bakım Veren Aile Üyelerinin Bakım Yükleri ve Yaşam Kaliteleri Üzerine Bir Gözden Geçirme. Düzce Üniversitesi Sağlık Bilimleri Enstitüsü Dergisi. 2012;2(3): 24-28.

19. Davison SN, Jhangri GS. TheRelationBetweenSpirituality, Psychosocial Adjustment To Illness, And Health-Related Quality Of Life In Patients With Advanced Chronic Kidney Disease. Journal of Pain and Symptom Management. 2013; $\begin{array}{lllll}\text { Vol. } & 45 & \text { No. } & 2 & \text { February, } \\ \text { 170-78. }\end{array}$ http://dx.doi.org/10.1016/j.jpainsymman.2012.02.019.

20. Özkaraman A, Balcı Alparslan G, Gökçe S, Babadağ B, Gölgeli H, Derin Ö, Bilgin M. Hemodiyaliz Yapılan Kronik Böbrek Hastalarında Sağlıklı Yaşam Biçimi Davranışlarının Değerlendirilmesi. Osmangazi Tip Dergisi/ Osmangazi Journal of Medicine. 2016; 38: 1-11. Eskişehir. DOI: http://dx.doi.org/10.20515/otd.54752

21. Krespı MR, Bone M, Ahmad R, Worthington B, Salmon P. Hemodialysis Patients' Evaluation of Their Lives. Türk Psikiyatri Dergisi. 2008; 19(4),1-8.

22. Ginieri-Coccossis M, Theofilou P, Synodinou C, Tomaras V, Soldatos C. QualityOfLife, Menta 1Health And Health Beliefs In Haemodialysis And Peritoneal Dialysis Patients: Investigating Differences In Early And Later Years Of Current Treatment. BMC Nephrology. 2008; 9:14, 1-9.

23. Finnegan-John F, Thomas VJ. The Psychosocial Experience of Patients with End-Stage Renal Disease and Its Impact on Quality of Life: Findings from a Needs Assessment to Shape a Service. Hindawi Publishing Corporation, ISRN Nephrology. 2012; Volume, Article ID 308986,1-9. http://dx.doi.org/10.5402/2013/308986.

24. Akbulut Çavuş Ö, Üstün Geyik E. Hemodiyaliz Hastalarının Tedaviye Ve Diyete Uyumları İle Yaşam Kalitesi Düzeylerinin Değerlendirilmesi Türk Böbrek Vakfi Diyaliz Merkezi Örneği, 
Kronik böbrek hastalarının yaşam deneyimleri.

Okçin Albayrak F, Yeşilbalkan Usta Ö.

Namık Kemal Üniversitesi Sosyal Bilimler Enstitüsü Sağlık Yönetimi Anabilim Dalı YL Tezi. 2016.

25. Allen D, Wainwright M, Hutchinson T. Non-Compliance'

As Illness Management: Hemodialysis Patients'

Descriptions Of Adversarial Patient-clinician Interactions.

SocialScience \& Medicine. 2011; 73,129-134.

doi:10.1016/j.socscimed.2011.05.018. 